\title{
Physiology of Paluma guava plants fertilized with potassium and calcium
}

\author{
Fisiología en plantas de guayaba Paluma fertilizadas con calcio y potasio
}

\author{
Alian Cássio Pereira Cavalcante ${ }^{*}$, Lourival Ferreira Cavalcante ${ }^{2}$, Adailza Guilherme Cavalcante ${ }^{3}$, \\ Antonio Michael Pereira Bertino ${ }^{3}$, Antonio Missiemario Pereira Bertino ${ }^{2}$ y Nubia Marisa Ferreira ${ }^{4}$
}

\begin{abstract}
Guava is a perennial fruit, highly preferred by the Brazilian consumer and in increasing commercial exploitation in almost all the national territory. The most required nutrients are nitrogen, followed by potassium and calcium with great participation in the growth and physiology of guava. The objective of this study was to evaluate the effects of potassium doses in the soil without and with calcium in the physiology of Paluma guava plants. The experiment was carried out in a randomized complete block design in a $5 \times 2$ factorial arrangement, with $\mathrm{K}_{2} \mathrm{O}$ of $0,45,90,135$ and $180 \mathrm{~g} \mathrm{plant}^{-1}$ year ${ }^{-1}$, without and with $120 \mathrm{~g} \mathrm{plant}^{-1}$ year $^{-1} \mathrm{calcium}$ from calcium nitrate. The variables analyzed were chlorophyll indices ( $\mathrm{a}, \mathrm{b}$ and total), chlorophyll fluorescence and gas exchange. The results were submitted to analysis of variance by the " $\mathrm{F}$ " test and the potassium doses were submitted to regression analysis, using $\mathrm{SAS}^{\odot}$ software version 9.3. Guava plants fertilized with only potassium in the soil had higher photosynthetic rate, water use efficiency and instantaneous carboxylation efficiency. The addition of calcium and potassium to the soil increased chlorophyll a, $\mathrm{b}$, total, variable fluorescence, maximum fluorescence, quantum efficiency, stomatal conductance, transpiration rate and internal carbon concentration in guava.
\end{abstract}

Key words: Psidium guajava, chlorophyll, physiological aspects

\section{RESUMEN}

La guayaba es una planta perenne, de alta preferencia por los consumidores brasileños y generando esto un crecimiento operacional en su comercio en casi todo el territorio nacional. Nutricionalmente, los nutrientes más necesarios son nitrógeno, potasio y calcio, con gran participación en el crecimiento y fisiología de la guayaba. Teniendo en cuenta lo anterior, el objetivo fue evaluar los efectos de dosis de potasio en el suelo con y sin calcio en la fisiología de la guayaba con la variedad Paluma. El experimento se realizó en un bloque completamente aleatorizado con arreglo factorial $5 \times 2$, relativo al suelo con dosis de K2O de 0, 45, 90, 135 y $180 \mathrm{~g} \mathrm{planta}^{-1}$ año-1 y sin y con $120 \mathrm{~g} \mathrm{planta}^{-1}$ año $\mathrm{o}^{-1}$ de calcio derivado del nitrato de calcio. Las variables analizadas fueron las tasas de clorofila ( $a, b, y$ total) fluorescencia de la clorofila y el intercambio gaseoso. Los resultados fueron sometidos a la prueba por análisis de varianza " $F$ " y las doses de potasio fueron sometidos a análisis de regresión, utilizando el software SAS versión 9.3 (․ Las plantas de guayaba fertilizados solamente con el potasio en el suelo, mostraron una mayor tasa de fotosíntesis, el uso eficiente del agua y la eficiencia instantánea de carboxilación. La adición de calcio y potasio en el suelo aumentó los índices de clorofila $a, b$, total, fluorescencia variable, el máximo rendimiento cuántico de fluorescencia, conductancia estomática, tasa de transpiración e concentración interna de carbono en la planta de guayaba.

Palabras clave: Psidium guajava, clorofila, aspectos fisiológicos

\section{Introduction}

Guava (Psidium guajava $\mathrm{L}$.) is native to tropical America, commonly found in the entire Brazilian territory and cultivated in commercial orchards. Its fruits have a pleasant flavor and wide market acceptance, both for in natura consumption and for pulp processing in industries (Oliveira et al., 2015).

\footnotetext{
Universidade Federal de Viçosa, Viçosa - Minas Gerais, Brazil.

Universidade Federal da Paraiba. Areia - Paraíba, Brazil

Universidade Estadual Paulista - FCAV/UNESP, Jaboticabal, São Paulo, Brasil.

Universidade Federal Rural do Semi-Árido. Mossoró, Rio Grande do Norte, Brazil.

*_corresponding author: cassio.alian216@gmail.com; alian.cavalcante@ufv.br
}

Fecha de Recepción: 28 agosto, 2017.

Fecha de Aceptación: 01 marzo, 2018.

DOI: http://dx.doi.org/10.4067/S0718-34292018005000503. Publicado en línea: 20-agosto-2018. 
It belongs to the Myrtaceae family and has an enormous potential for commercial cultivation in Brazil (Souza et al., 2012).

Potassium (K) is the second most required essential nutrient for guava plants (Franco et al., 2007). This nutrient displays a variety of physiological functions such as control of cellular turgidity, activation of enzymes used in respiration processes, protein synthesis, water relations, photosynthesis, stomatal opening and closure regulation, carbohydrate transport and transpiration, thus contributing to plant development and increasing production (Zorb et al., 2014).

The supply of $\mathrm{K}$ during the photosynthetic process is not well understood, justifying new research that simultaneously analyzes gas exchange and chlorophyll in order to evaluate the effect of $\mathrm{K}$ on the photosynthetic efficiency in plants (Jin et al., 2011). Besides potassium, calcium plays an important role in the development of fruit trees, as it provides greater membrane firmness of the cell wall, directly affecting the quality of the final product (Natale et al., 2005).

Nutrient deficiency may lead to irregular functioning of stomata, reducing $\mathrm{CO}_{2}$ assimilation and photosynthetic rate of plants, thus affecting crop production (Feitosa et al., 2013). Based on the above, we aimed to evaluate the effect of different doses of potassium on soil without and with calcium on the physiology of Paluma variety guava plants.

\section{Material and methods}

\section{Location and soil of the experimental area}

The experiment was performed from August 2015 to May 2016 at the property "Sítio Macaquinhos", located in the municipality of Remígio, Paraíba, Brazil. The experimental area's soil was classified as Dystrophic Regolitic Neosol by the criteria described in the Brazilian System of Soil Classification SIBCS (EMBRAPA, 2013). Before the experiment installation, in April, 2015 fifteen soil samples were collected from the 0-40 layer (five in each block) in the area below the projection of the tree canopy, which were transformed into one composite sample, whose soil fertility characteristics and physical attributes were analyzed (Table 1). The eutrophic nature of the soil, with a base saturation of $56.3 \%$, is due to conventional fertilization with $\mathrm{N}, \mathrm{P}, \mathrm{K}$ and organic matter in previous years.

\section{Experimental design and treatments}

The experimental design was of randomized blocks in a $2 \times 5$ factorial scheme: soil with and without $120 \mathrm{~g} \mathrm{plant}^{-1}$ year $^{-1}$ calcium derived from calcium nitrate $\left(19.0 \% \mathrm{Ca}^{2+}\right.$ and $\left.15.5 \% \mathrm{~N}\right)$; and potassium chloride $\left(56 \% \mathrm{~K}_{2} \mathrm{O}\right)$ at doses of $0,45,90,135$ and 180 g plant $^{-1}$ year $^{-1} \mathrm{~K}_{2} \mathrm{O}$ ), with three replicates and three plants per plot in an orchard installed in June 2014, 13 months old. Both calcium and potassium doses were applied in the projection area of the tree canopy apportioned in three equal shares, one immediately after the pruning of lateral branches, one at the beginning of blooming and one 30 days after full blooming.

\section{Plants fertilization and irrigation}

Fertilizations with N, P and K were performed as described by Natale et al. (2009). The nitrogen fertilization consisted of $160 \mathrm{~g}$ plant $^{-1}$ year $^{-1}$ of $\mathrm{N}$ from urea $(45 \% \mathrm{~N})$, discounting the amount added by calcium nitrate and monoammonium phosphate, supplied in three stages: $30 \%$ after pruning (08/05/2015), 30\% at the beginning of blooming and $40 \% 30$ days after full blooming.

The doses of potassium chloride $\left(56 \% \mathrm{~K}_{2} \mathrm{O}\right)$ were also divided into 30,30 and $40 \%$ shares, along with nitrogen. The source of phosphorus was monoammonium phosphate (MAP with $49 \% \mathrm{P}_{2} \mathrm{O}_{5}$ and $10 \% \mathrm{~N}$ ) at the dose of $120 \mathrm{~g} \mathrm{P}_{2} \mathrm{O}_{5}$ plant $^{-1}$ year $^{-1}$ from purified MAP, divided in three doses of 50, 25 and $25 \%$ applied simultaneously with nitrogen and potassium. The dose of calcium was $120 \mathrm{~g}$ plant $^{-1}$ year ${ }^{-1}$, deriving from calcium nitrate $(19.0 \%$ $\mathrm{Ca}^{2+}$ and $15.5 \% \mathrm{~N}$ ), also divided in 50, 25 and $25 \%$.

A deficiency in zinc and magnesium may exist in the soil, which was superficially fertilized with $20 \mathrm{~g}$ of zinc sulfate $(20 \% \mathrm{Zn})$ and $30 \mathrm{~g}$ of magnesium sulfate $(9 \% \mathrm{Mg})$ per plant, together with the first NPK fertilization. A supplementation of boron was performed through leaves in three pulverization processes with borax (11\% B), as suggested by Natale et al. (2009).

Plant irrigation during the dry season (August 2015 to April 2016) was performed based on the potential evapotranspiration obtained from the evaporation of the "class A" tank installed in the experimental area. The crop coefficient $(\mathrm{Kc})$ was used as suggested by Ferreira (2004), according to the phenological stage: sprout and vegetative 
Table 1. Chemical and physical attributes of the soil in the 0-40 layer before installation of the experiment.

\begin{tabular}{cccc}
\hline Chemical Attributes & Value & Physical Attributes & Value \\
\hline $\mathrm{pH}\left(\mathrm{H}_{2} \mathrm{O}\right)$ & 5.53 & Coarse Sand $\left(\mathrm{g} \mathrm{kg}^{-1}\right)$ & 544 \\
$\mathrm{P}\left(\mathrm{mg} \mathrm{dm}^{-3}\right)$ & 9.7 & Fine Sand $\left(\mathrm{g} \mathrm{kg}^{-1}\right)$ & 283 \\
$\mathrm{~K}^{+}\left(\mathrm{cmol}_{\mathrm{c}} \mathrm{dm}^{-3}\right)$ & 0.13 & Silt $\left(\mathrm{g} \mathrm{kg}^{-1}\right)$ & 91 \\
$\mathrm{Ca}^{+2}\left(\mathrm{cmol}_{\mathrm{c}} \mathrm{dm}^{-3}\right)$ & 1.79 & Clay $\left(\mathrm{g} \mathrm{kg}^{-1}\right)$ & 83 \\
$\mathrm{Mg}^{+2}\left(\mathrm{cmol}_{\mathrm{c}} \mathrm{dm}^{-3}\right)$ & 0.48 & Diffuse Clay $\left(\mathrm{g} \mathrm{kg}^{-1}\right)$ & 19 \\
$\mathrm{Na}^{+}\left(\mathrm{cmol}_{\mathrm{c}} \mathrm{dm}^{-3}\right)$ & 0.010 & Flocculation Degree $(\%)$ & 77.2 \\
$\mathrm{SB}\left(\mathrm{cmol}_{\mathrm{c}} \mathrm{dm}^{-3}\right)$ & 2.41 & Dispersion Index $(\%)$ & 28.2 \\
$\mathrm{H}^{+}+\mathrm{Al} l^{+3}\left(\mathrm{cmol}_{\mathrm{c}} \mathrm{dm}^{-3}\right)$ & 1.85 & Soil Density $\left(\mathrm{g} \mathrm{cm}^{-3}\right)$ & 1.58 \\
$\mathrm{Al}{ }^{+3}\left(\mathrm{cmol}_{\mathrm{c}} \mathrm{dm}^{-3}\right)$ & 0.0 & Particle Density $\left(\mathrm{g} \mathrm{cm}^{-3}\right)$ & 2.64 \\
$\mathrm{CTC}\left(\mathrm{cmol}_{\mathrm{c}} \mathrm{dm}^{-3}\right)$ & 4.26 & Total Porosity $\left(\mathrm{m}^{3} \mathrm{~m}^{-3}\right)$ & 0.40 \\
$\mathrm{~V}(\%)$ & 56.3 & Microporosity $(\%)$ & 16.3 \\
$\mathrm{MOS}\left(\mathrm{g} \mathrm{kg}^{-1}\right)$ & 13.1 & Macroporosity $(\%)$ & 83.7 \\
$\mathrm{~S}\left(\mathrm{mg} \mathrm{dm}^{-3}\right)$ & 7.20 & Humidity - 0.010 MPa $\left(\mathrm{g} \mathrm{kg}^{-1}\right)$ & 64.83 \\
$\mathrm{~B}\left(\mathrm{mg} \mathrm{dm}^{-3}\right)$ & 0.19 & Humidity - 0.033 MPa $\left(\mathrm{g} \mathrm{kg}^{-1}\right)$ & 48.03 \\
$\mathrm{Cu}\left(\mathrm{mg} \mathrm{dm}^{-3}\right)$ & 0.80 & Humidity - $1.500 \mathrm{MPa}\left(\mathrm{g} \mathrm{kg}^{-1}\right)$ & 25.05 \\
$\mathrm{Mn}\left(\mathrm{mg} \mathrm{dm}^{-3}\right)$ & 7.40 & Available water $\left(\mathrm{g} \mathrm{kg}^{-1}\right)$ & 39.78 \\
$\mathrm{Fe}\left(\mathrm{mg} \mathrm{dm}^{-3}\right)$ & 54.0 & & \\
$\mathrm{Zn}\left(\mathrm{mg} \mathrm{dm}^{-3}\right)$ & 1.84 & & \\
\hline
\end{tabular}

growth (0.68); vegetative growth, blooming and physiological fruit drop (0.76); fruit growth (0.71) and fruit maturation and harvest (0.62). The irrigation system adopted was by micro-sprinkler with an application efficiency of $92 \%$, by means of an emitter with a flow of $60 \mathrm{~L} \mathrm{~h}^{-1}$ per plant, installed at a height which wet all the area of canopy projection, working with a service pressure of $0.2 \mathrm{MPa}$.

\section{Measurement of ' $a$ ', ' $b$ ' and total chlorophyll indexes in plants}

Chlorophyll $a, b$ and total indexes were determined during the flowering period, 90 days after first fertilization, between 8 and $10 \mathrm{AM}$, by means of an electronic chlorophyll meter (ClorofilLOG ${ }^{\circledR}$, model CFL 1030). The measured values are expressed in the Falker chlorophyll index (FCI), which refers to the product of photodiodes that emit waves at the frequencies 635, 660 and 880 $\mathrm{nm}$. The evaluations were performed in one plant of each plot, collecting the third leaf pair completely developed (Natale et al., 2007). Readings were performed in four quadrants of four leaves, on the superior, middle and inferior part of each leaf to estimate the mean value per leaf.

\section{Fluorescence of chlorophyll " $a$ "}

The chlorophyll $a$ fluorescence measurements were made 90 days after first fertilization (from 8 to $10 \mathrm{AM}$ ) in leaves sampled from the third completely developed pair, with the aid of a fluorimeter (Plant Efficiency Analyzer PEA II ${ }^{\circledR}$ - Hansatech Instruments Co., UK). Leaf areas were adapted to the dark for 30 minutes, using fluorescence tweezers. We evaluated the initial fluorescence parameter $(\mathrm{F} 0)$, variable (Fv) and maximum (Fm) fluorescence and quantum efficiency of photosystem II ( $\mathrm{Fv} / \mathrm{Fm})$.

\section{Gas exchange}

Gas exchange was evaluated at full flowering (90 days after first fertilization, on 11/05/2015), when plants were 16 months old. The evaluations were performed in the third pair of completely developed leaves, from the apical meristem of branches at both quadrants of the plant, by means 
of a $\mathrm{CO}_{2}$ analyzer with a portable infrared radiation (IRGA), model LCPro ${ }^{+}$Portable Photosynthesis System ${ }^{\circledR}$ (ADC BioScientific Limited, UK), with a temperature control of $25^{\circ} \mathrm{C}$, artificial controlled irradiation of $1200 \mu \mathrm{mol}$ photons $\mathrm{m}^{-2} \mathrm{~s}^{-1}$ and air flow of $200 \mathrm{ml} \mathrm{min}^{-1}$. The physiological variables determined were stomatal conductance (gs), transpiration (E), photosynthetic rate (A), internal concentration of $\mathrm{CO}_{2}(\mathrm{Ci})$, water use efficiency $(\mathrm{A} / \mathrm{E})$ and instantaneous efficiency of carboxylation (A/ $\mathrm{Ci})$, evaluated between 8 and $10 \mathrm{AM}$.

\section{Statistical Analysis}

All data were submitted to a variance analysis and the means for fertilization with and without calcium were compared by the F test. Potassium doses were analyzed by regression and all analyses were performed with the software Statistical Analysis System (SAS ${ }^{\circledR} /$ STAT 9.3, 2011).

\section{Results and discussion}

\section{Guava plant physiology}

The increase of potassium dose in soil without calcium stimulated the chlorophyll process of

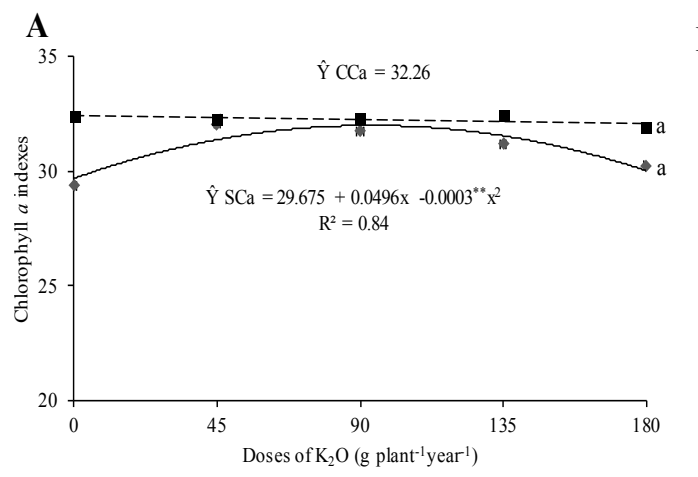

plants; the chlorophyll " $a$ " index reached 31.72 at the maximum estimated dose of $\mathrm{K}_{2} \mathrm{O}$ of 82.7 g plant $^{-1}$ year-1 (Figure 1A), since $\mathrm{K}_{2} \mathrm{O}$ doses above this value jeopardized the chlorophyll activity of plants. The same figure shows that despite the potassium $\mathrm{x}$ calcium interaction, calcium exerted a significant action on the chlorophyll $a$ indexes, since the values did not fit any regression model and corresponded to the average of 32.26 according to $\mathrm{K}_{2} \mathrm{O}$ doses. Similarity between plants in soil with and without calcium diverges from the results obtained by Siddiqui et al. (2012), who found that the interaction between potassium and calcium stimulates the production of chlorophyll $a$ in plants of wild fava bean (Vicia faba L.).

Similarly to chlorophyll $a$, potassium increases in soil without calcium raised the chlorophyll $b$ index, reaching the highest index of 16.97 at the maximum estimated $\mathrm{K}_{2} \mathrm{O}$ dose of $97 \mathrm{~g}_{\text {plant }}{ }^{-1}$ year ${ }^{-1}$, while in plants on soil with calcium the results did not fit any model, with a mean value of 16.58 (Figure 1B). For Jesus \& Marenco (2008) a positive relation between chlorophyll activity and photosynthetic rate on plants growth exists, which was also verified in guava plants.

The total chlorophyll of plants in soil without calcium increased with potassium doses up to the

B

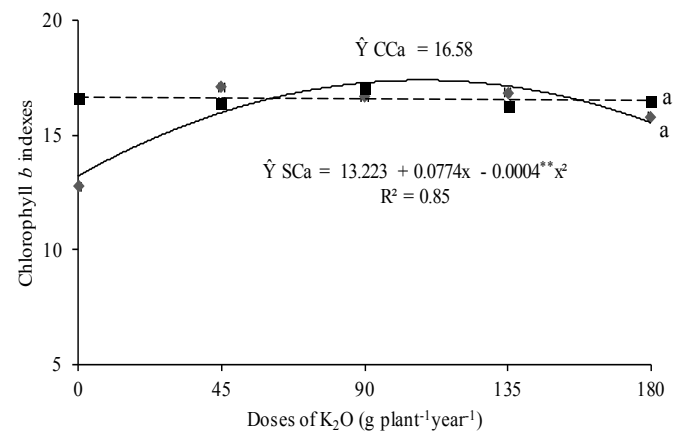

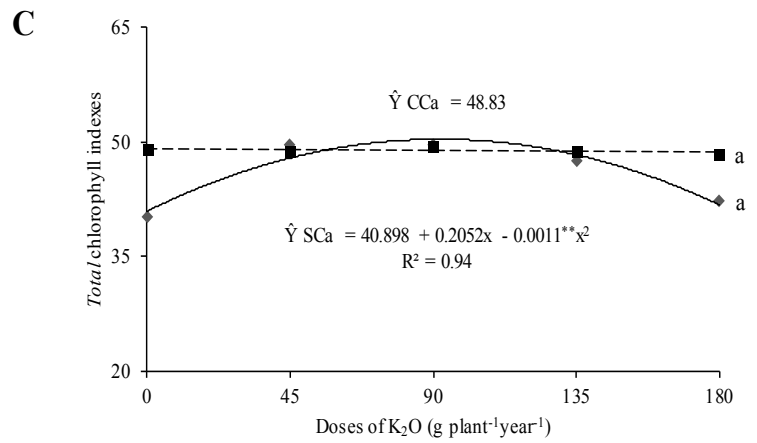

Figure 1. Chlorophyll a, b and total in Paluma guava plants as a function of different doses of potassium in soil without SCa (一) and with $\mathrm{CCa}(---)$ calcium. 
highest index of 50.47 at the maximum estimated $\mathrm{K}_{2} \mathrm{O}$ dose of 93 g plant $^{-1}$ year $^{-1}, 23.4 \%$ greater than plants in soil without potassium (Figure 1C). These results concur with Jin et al. (2011), who concluded that potassium also stimulates total chlorophyll contents and has effects on the regulation of photochemical processes in Carya cathayensis.

The variable fluorescence (Fv), which corresponds to the difference between maximum (Fm) and initial (Fo) fluorescence, increased linearly with potassium dose in soil with calcium up to the maximum estimated dose of $84 \mathrm{~g}$ plant $^{-1}$ year $^{-1}$ of $\mathrm{K}_{2} \mathrm{O}$, in plants in soil without calcium (Figure 2). Fv values in soil without calcium increased from 179.9 to 236.4 , corresponding to an increase of $31.4 \%$ between plants in soil without and with the maximum estimated dose of $\mathrm{K}_{2} \mathrm{O}$.

It is noteworthy that potassium doses above $84 \mathrm{~g} \mathrm{plant}^{-1}$ year $^{-1}$ reduced the Fv of Paluma guava plants. Plants in soil with calcium had an increasing linear Fv as a function of potassium dose. The highest Fv value at the greatest potassium dose with calcium indicates higher fluorescence intensity, when quinone is reduced and the reaction centers reach full capacity of photochemical reactions (Baker \& Rosenqust, 2004; Silva et al., 2015).

Guava plants that received calcium fertilization had a greater increment in maximum fluorescence when potassium doses were elevated. In plants that were cultivated without calcium, increasing potassium dose produced better performance with the dose of 82.5 g plant $^{-1}$ year ${ }^{-1} \mathrm{~K}_{2} \mathrm{O}$ (Figure 3), showing a reduction of the deficiency in the photoreduction of quinone and on the electron flow between photosystems in treatments without calcium (Tatagiba et al., 2014).

Quantum efficiency expresses the light absorbed by photosystem II and is represented by the relation

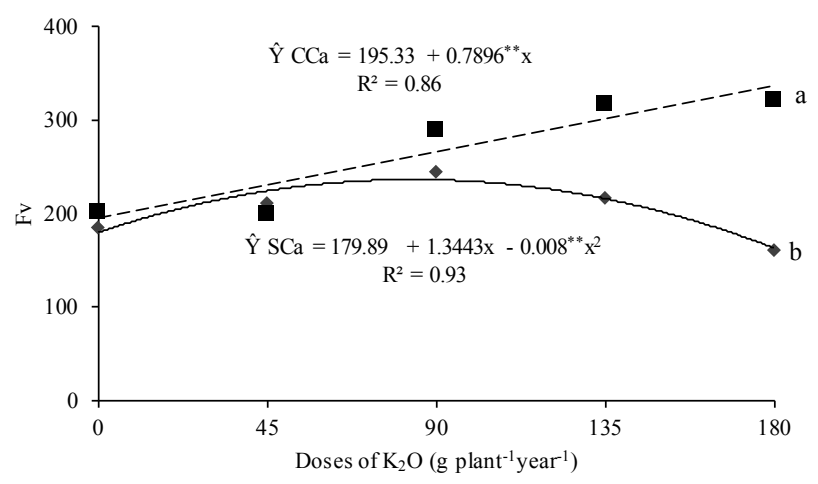

Figure 2. Variable fluorescence (Fv) in Paluma guava plants as a function of potassium doses in soil without $\mathrm{SCa}(-)$ and with $\mathrm{CCa}(---)$ calcium.

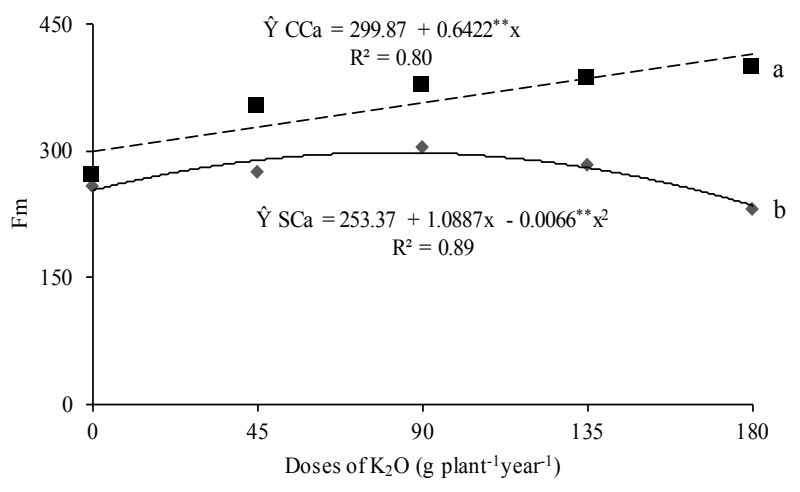

Figure 3. Maximum fluorescence (Fm) in Paluma guava plants as afunction of potassium doses in soil without $\mathrm{SCa}(-)$ and with $\mathrm{CCa}$ (---) calcium. 
between variable and maximum fluorescence $(\mathrm{Fv} /$ Fm). It serves as an indicator of the photosynthetic performance of plants (Taiz \& Zeiger, 2013). The application of calcium linearly increased the quantum efficiency of photosystem II (Figure 4); however, all treatments had values above the recommended level, with optimum values between 0.75 and 0.85 for most species (Bolhàr-Nordenkampf et al., 1989; Silva et al., 2015).

The stomatal conductance of guava plants was higher in treatments with the addition of potassium and calcium in soil (Figure 5), which may have provided a greater regulation of the cell wall and consequently an increase in stomatal conductance (Simonsson et al., 2016). The addition of potassium led to the lowest stomatal conductance found, however, the lowest opening and closing of the stomas provided a great regulation of the water pressure and an increment in the photosynthetic rate during transpiration (Schreiner et al., 2013), which resulted in better water use efficiency.

Plants showed greater transpiration rates as potassium dose increased in soil with the addition of calcium, while in treatments without calcium, a potassium dose of $90 \mathrm{~g}_{\text {plant }}{ }^{-1}$ year $^{-1}$ showed the lowest transpiration rate, thus providing the best $\mathrm{CO}_{2}$ assimilation (Figure 6). Adequate availability of $\mathrm{K}$ improves the control of water loss by transpiration (Benlloch-González et al., 2016), besides providing greater photosynthetic rate efficiency. The offer of calcium to plants is strongly connected to transpiration, since this nutrient is deposited in vacuoles and is barely redistributed, which results in organs with high transpiration rates when there is increased calcium concentration in the vacuoles (Gilliham et al., 2011).

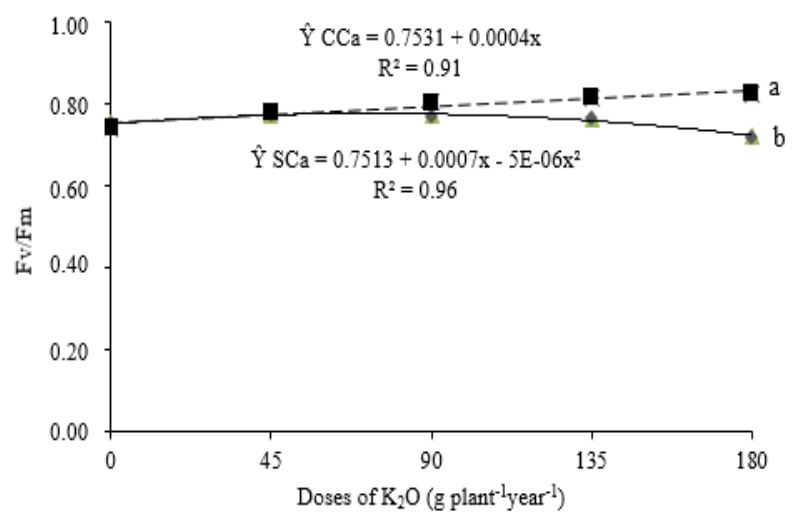

Figure 4. Quantum efficiency of the photosystem II (Fv/Fm) in Paluma guava plants in soil without $\mathrm{SCa}(-)$ and with $\mathrm{CCa}(---)$ calcium.

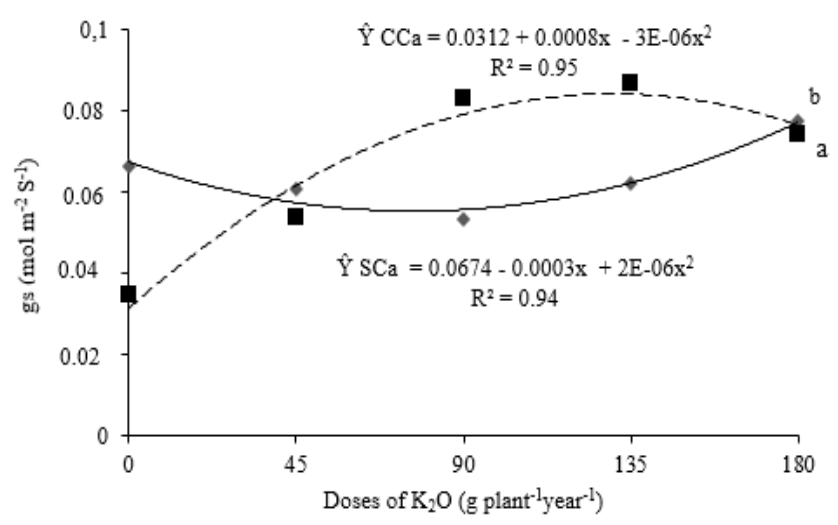

Figure 5. Stomatal conductance (gs) in Paluma guava plants as a function of potassium dose in soil without SCa (-) and with CCA (---) calcium. 


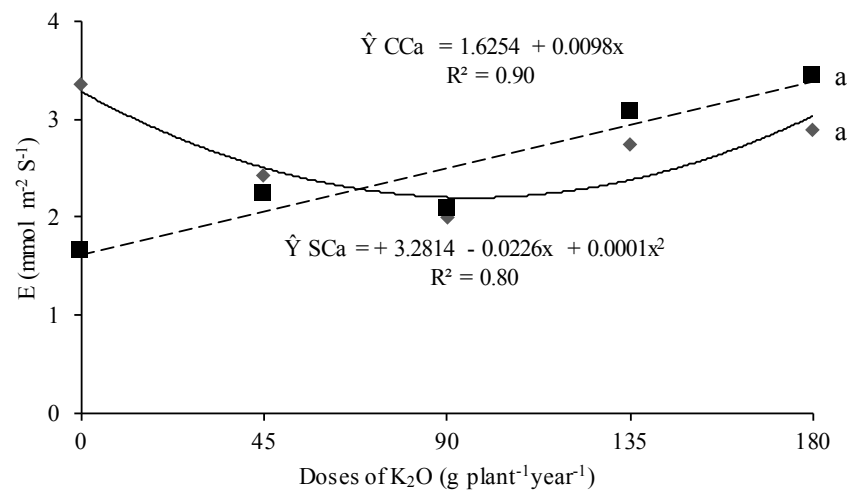

Figure 6. Transpiration rate (E) in Paluma guava plants as a function of potassium dose in soil without SCa (-) and with CCA (---) calcium.

Potassium fertilization allowed a greater photosynthetic rate at the estimated dose of $101 \mathrm{~g}$ plant $^{-1}$ year $^{-1}$, consistent with the production per plant in treatments where calcium was not applied (Figure 7). Whencalcium was added, the photosynthetic rate increased along with potassium dose. For this reason it is necessary to identify the optimum estimated dose, given that the deficiency of this nutrient may lead to irregular stomatal functioning and in adequate levels the photosynthetic rate can be elevated, thus increasing crop production (Feitosa et al., 2013).

Fertilization with potassium without calcium provided greater water use efficiency, with high performance at the estimated dose of $96 \mathrm{~g}^{\text {plant }}{ }^{-1}$ year ${ }^{-1}$, possibly because potassium is one of the most demanded nutrients for guava plants (Figure 8). This efficiency is directly compatible with the photosynthetic rate and the production per plant in the treatment without calcium nitrate. Potassium exerts physiological functions such as the control of cell turgidity, activation of enzymes involved in respiration, water relations, photosynthesis, regulation of the opening and closure of stomas, transport of carbohydrates and transpiration, thus contributing to better development (Zorb et al., 2014).

Guava plants presented higher internal concentrations of $\mathrm{CO}_{2}$ when potassium and calcium were applied to the soil (Figure 9). When potentially nourished with potassium, both water use and

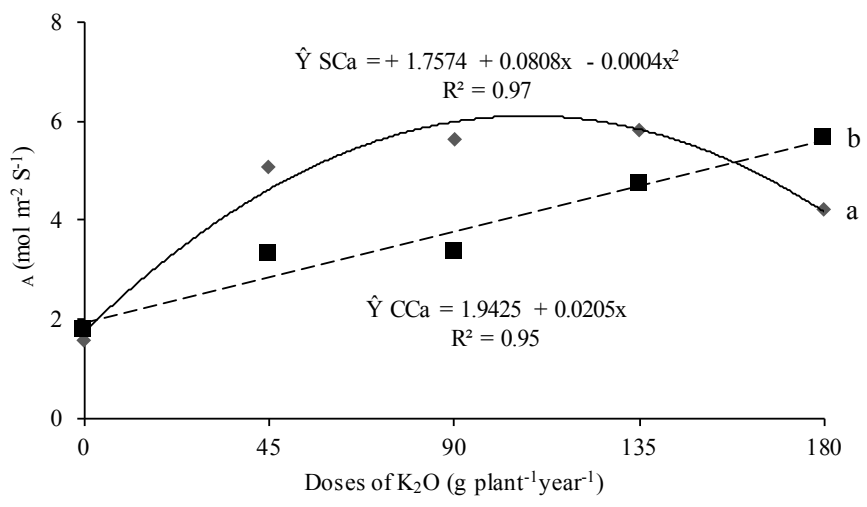

Figure 7. Photosynthetic rate (A) in Paluma guava plants as a function of potassium dose in soil without SCa (-) and with CCA (---) calcium. 


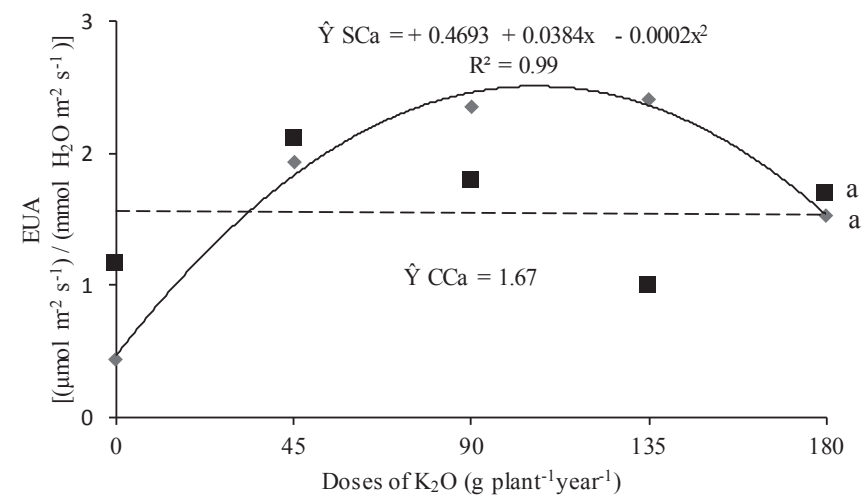

Figure 8. Instantaneous efficiency of water use (EUA) in Paluma guava plants as a function of potassium dose in soil without $\mathrm{SCa}(-)$ and with $\mathrm{CCA}(---)$ calcium.

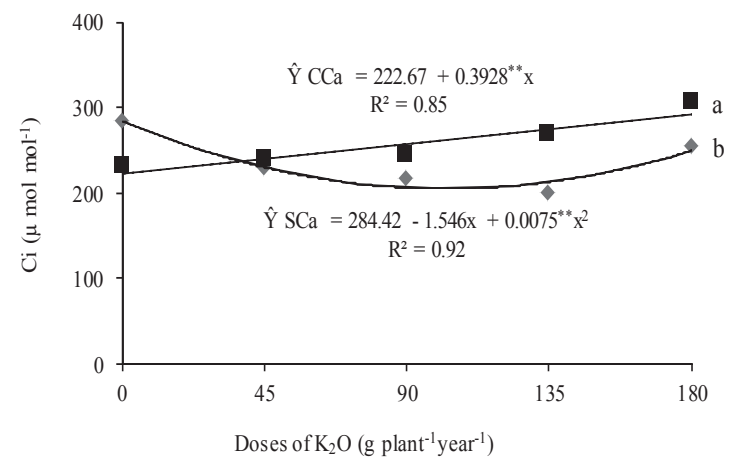

Figure 9. Internal concentration of carbon dioxide $\left(\mathrm{CO}_{2}\right)$ in Paluma guava plants as a function of potassium dose in soil without $\mathrm{SCa}$ (-) and with CCA (---) calcium.

photosynthetic rate were higher due to the regular stomatal opening, which provokes greater carbon assimilation (Prado, 2008).

The highest instantaneous carboxylation efficiencies were obtained in treatments without the addition of calcium in potassium fertilization (Figure 10), possibly due to the competition between these two nutrients in the soil solution. Thus treatments that did not receive calcium were more efficient, since potassium participates in the regulation of physiological and biochemical processes that influence plant metabolism (Wang et al., 2013). The figure shows that potassium acts in a decisive way on the instantaneous carboxylation efficiency.

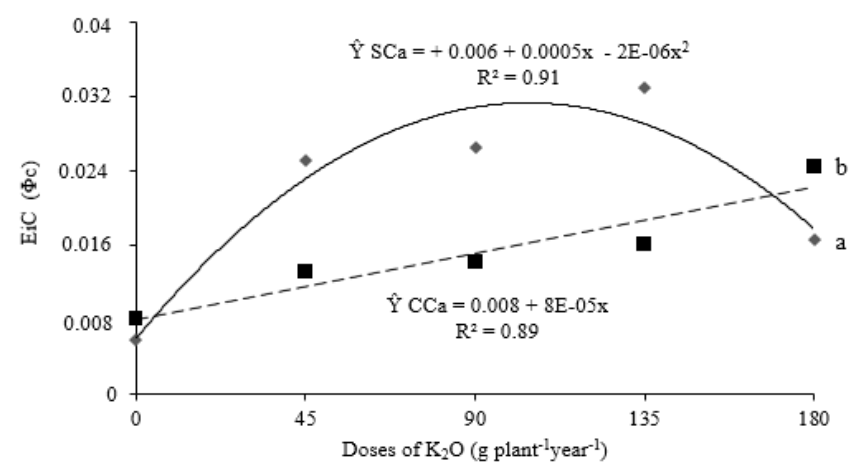

Figure 10. Instantaneous efficiency of carboxylation (EiC), in Paluma guava plants as a function of potassium dose in soil without $\mathrm{SCa}(-)$ and with $\mathrm{CCA}(---)$ calcium. 


\section{Conclusions}

Guava plants fertilized only with potassium presented the highest photosynthetic rate, water use efficiency and instantaneous efficiency of carboxylation.

The addition of calcium and potassium to soil increased the chlorophyll $a, b$ and total indexes, as well as variable and maximum fluorescence, quantum efficiency, stomatal conductance, transpiration rate and internal concentration of carbon in guava plants.

Potassium is a key nutrient in the photosynthetic response of Paluma guava plants, being responsive in all analyzed variables.

\section{Literature Cited}

Baker, N. R.; Rosenqust, E.

2004. Aplication of chlorophyll fluorescence can improve crop production strategies: an examination of future possibilities. Journal of Experimental Botany, 403: 1607-1621.

Benlloch-Gonzáleza, M.; Quinterob, J. M.; Suárezb, M. P.; Sánchez-Lucasc, R.; Fernández-Escobara, R.; Benlloch, M.

2016. Effect of moderate high temperature on the vegetative growth and potassium allocation in olive plants. Journal of Plant Physiology, 207: 22-29.

Bolhar-Nordenkampf, H. R.; Long, S. P.; Baker, N. R.; Oquist,

G.; Schreiber, U.; Lechner, E. G.

1989. Chlorophyll fluorescence as probe of the photosynthetic competence of leaves in the field: a review of current instrumentation. Functional Ecology, 4: 497-514.

EMBRAPA - Empresa Brasileira de Pesquisa Agropecuária. 2013. Solos: Sistema Brasileiro de Classificação de Solos.

Ed. Embrapa Solos. Rio de Janeiro, Brasil. 353 p.

Feitosa, H. de O.; Farias, G. C.; Silva Junior, R. J. C.; Ferreira,

F. J.; Andrade Filho, F. L.; Lacerda, C. F.

2013. Influência da adubação borácica e potássica no desempenho do girassol. Comunicata Scientiae, 3: 302-307.

Ferreira, M. de N.L.

2004. Distribuição radicular e consumo de água de goiabeira (Psidiumguajava L.) irrigada por microaspersão em Petrolina. Piracicaba, Trabalho de Tese. Escola Superior de Agricultura "Luiz de Queiroz", Universidade de São Paulo. 106 p.

Franco, F. C.; Prado, R. M.; Brachirolli, L. F.; Rozane, D. E. 2007. Curva de crescimento e marcha de absorção de macronutrientes em mudas de goiabeira, Revista Brasileira de Ciência do Solo, 31: 1429-1437.

Gilliham, M.; Dayod, M.; Hocking, B. J.; Xu, B.; Conn, S. J.;

Kaiser, B. N.; Leigh, R. A.; Tyerman, S. D.

2011. Calcium delivery and storage in plant leaves: exploring the link with water flow. Journal of Experimental Botany, 62: 2233-2250.

Jesus, S. V. de; Marenco, R. A

2008. O SPAD-502 como alternativa para a determinação dos teores de clorofila em espécies frutíferas. Acta Amazonica, 30: $815-818$

Jin, S. H.; Huang, J. Q.; Li, X. Q.; Zheng, B. S.; Wu, J. S.; Wang,

Z. J.; Liu, G. H.; Chen, M.

2011. Effects of potassium supply on limitations of photosynthesis by mesophyll diffusion conductance in Caryacathayensis. Tree Physiology, 31: 1142-1151.
Natale, W.; Prado, R. M.; Môro, F. V.

2005. Alterações anatômicas induzidas pelo cálcio na parede celular de frutos de goiabeira. Pesquisa Agropecuária Brasileira, 40: 1239-1242.

Natale, W.; Prado, R. M.; Quaggio, J. A.; Matto s Júnior, D. Guava. In: Crisósto M.O, L. A.; Naumov, A.; Johnston, A. E. 2007. Fertilizing for high yield and quality tropical fruits of Brazil. International Potash Institute. Horgen,Switzerland. pp. 103-122.

Natale, W.;Rozane, D. E.; Souza, H. A. de.; Amorim, D. A. de. 2009. Cultura da goiaba: do plantio a comercialização. FUNEP. Jaboticabal, Brazil. 284 p.

Oliveira, F. T. de.;Hafle, O. M.; Mendonça, V.; Moreira, J. N.; Pereira Junior, E. B.; Rolim, H. O.

2015. Respostas de porta-enxertos de goiabeira sob diferentes fontes e proporções de materiais orgânicos. Comunicata Scientiae, 6: 17-25.

Prado R. M.; Natale W.

2008. Effect of Liming on the Mineral Nutrition and Yield of Growing Guava Trees in a Typic Hapludox Soil. Communications in Soil Science and Plant Analysis, 39: 2191-2204.

SAS Institute Inc.

2011. SAS/STAT 9.3 User's Guide. SAS Institute Inc. Cary, NC, US. 8621 p.

Schreiner, R. P.; Lee, J.; Skinkis, P. A.

2013. N, P, and K Supply to Pinot noir Grapevines: Impact on vine nutrient status, growth, physiology, and yield. American Journal of Enology and Viticulture, 64: 26-38.

Siddiqui, M. H.; Al-whaibi, M. H.; Sakran, A. M.; Basalah, M. O.; Ali, H. M.

2012. Effect of calcium and potassium on antioxidant system of Viciafaba L. under cadmium stress. International Journal of Molecular Sciences, 13: 6604-6619.

Silva, F. G.; Dutra, W. F.; Dutra, A. F.; Oliveira, I. M.; Figueiras,

L. M. B.; Melo, A. S.

2015. Trocas gasosas e fluorescência da clorofila em plantas de berinjela sob lâminas de irrigação. Revista Brasileira de Engenharia Agrícola e Ambiental, 19: 946-952.

Simonsson, M.; Court, M.; Bergholm, J.; Lemarchand, D.; Hillier, S. 2016. Mineralogy and biogeochemistry of potassium in the Skogaby experimental forest, southwest Sweden: pools, fluxes and K/ $\mathrm{Rb}$ ratios in soil and biomass. Biogeochemistry, 131: 77-102.

Souza, H. A. de.; Rozane, D. E.; Romualdo, L. M.; Natale, W. 2012. Efeitos de diferentes tipos de poda nos teores de nutrientes em flores e frutos de goiabeira. Idesia, 30: 45-51. 
Wang, M.; Zheng, Q.; Shen, Q.; Guo, S.

2013. The critical role of potassium in plant stress response. International Journal of Molecular Sciences, 14: 7370-7390.

Taiz, L.; Zeiger, E.

2013. Fisiologia vegetal. Artmed Editora. Porto Alegre, Brazil. $820 \mathrm{p}$.
Tatagiba, S. D.; Moraes, G. A. B. K.; Nascimento, K. J. T.; Peloso, A.F. 2014. Limitações fotossintéticas em folhas de plantas de tomateiro submetidas a crescentes concentrações salinas. Revista Engenharia na Agricultura, 22: 138-149.

Zorb, C.; Senbayram, M.; Peiter, E.

2014. Potassium in Agriculture-Status and Perspectives. Journal of Plant Physiology, 171: 656-669. 